\title{
SARAH KANE CHEGA AO YOUTUBE: \\ 4.48 PSYCHOSIS, TRADUÇÃO E ADAPTAÇÃO EM TEMPOS DE CONVERGÊNCIA
}

\author{
Sarah Kane arrives at YouTube: \\ 4.48 Psychosis, translation and adaptation in times of convergence
}

\author{
Willian Henrique Cândido MOURA \\ Programa de Pós-Graduação em Estudos da Tradução \\ Universidade Federal de Santa Catarina \\ willianhenry_@hotmail.com \\ https://orcid.org/0000-0002-2675-6880
}

RESUMO: Neste artigo, utilizo como objetos de estudos a peça de teatro 4.48 Psychosis, de Sarah Kane, suas traduções não oficiais em português brasileiro e sua adaptação audiovisual divulgada no YouTube, Psicose 4h48, para realizar uma análise fílmica (cf. VANOYE; GOLIOT-LÉTÉ, 1994), a partir dos preceitos da Teoria da Adaptação (SEGER, 2007; HUTCHEON, 2013) e da Teoria da Tradução Intersemiótica (DINIZ, 1998; PLAZA, 2013), com o objetivo de identificar como a peça foi transposta para a tela digital. Tendo em vista os modos de compartilhamento e acesso às obras aqui analisadas, enfatizo o papel que a Cultura da Convergência e a Cultura Participativa (JENKINS, 2009) está exercendo nas transformações tecnológicas, industriais e sociais, principalmente no modo como as mídias circulam em nossa cultura e como a audiência está recebendo essas mídias. PALAVRAS-CHAVE: Sarah Kane; 4.48 Psychosis; Traduções não oficiais; Cultura da Convergência.

\begin{abstract}
In this article, I use Sarah Kane's play 4.48 Psychosis, its unofficial translations into Brazilian Portuguese, and its audiovisual adaptation shared on YouTube, Psicose 4h48, as material to carry out a film analysis (cf. VANOYE; GOLIOT-LÉTÉ, 1994), based on the Theory of Adaptation (SEGER, 2007; HUTCHEON, 2013), and the Theory of Intersemiotic Translation (DINIZ, 1998; PLAZA, 2013) in order to identify how the play was translated to the digital screen. Given the ways of sharing and accessing the materials analyzed, I emphasize the role that the Convergence Culture and the Participatory Culture (JENKINS, 2009) is playing in technological, industrial, and social changes, especially in the way that the media cir-
\end{abstract}

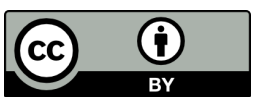


culate in our culture and how the audience is receiving these media. KEYWORDS: Sarah Kane; 4.48 Psychosis; Unofficial translations; Convergence Culture.

"4:48 Psychosis is a difficult play for which to provide a synopsis"

(ARMSTRONG, 2015)

\section{INTRODUÇÃO}

Teatro e cinema são duas formas de expressão artística cujo foco está na criação de imagens. Ao mesmo tempo em que se aproximam com relação ao objetivo, historicamente, distanciam-se devido ao modo como são produzidas. A proximidade desses gêneros parte da estrutura, pois ambos seguem um texto escrito que deverá ser performado/encenado por atores e atrizes. O distanciamento se dá em consequência da forma pela qual ocorre essa encenação: se de forma ao vivo, no teatro, ou de forma gravada, no cinema. Todavia, com a revolução digital que vivemos atualmente, essas formas tradicionais de produção e recepção, muitas vezes, acabam sendo modificadas visando a atender novas demandas da sociedade digital. A exemplo disso, Dubatti (2020) e Wexel (2021) são categóricos ao trazerem à tona a realidade do teatro imposta pela pandemia da Covid-19 em termos de formação de atores e atrizes on-line, produção teatral virtual, e exibição de peças via transmissão em plataformas de streaming, o que acaba criando convergências entre a linguagem teatral e a linguagem audiovisual.

Nesse sentido, tomando como objetos de estudos a peça de teatro intitulada 4.48 Psychosis, da dramaturga inglesa Sarah Kane, e sua adaptação para o vídeo Psicose $4 h 48$ (2012), disponibilizado na plataforma de compartilhamento de vídeos on-line YouTube, objetivo realizar uma análise fílmica (VANOYE; GOLIOT-LÉTÉ, 1994), a partir dos preceitos da Teoria da Adaptação (HUTCHEON, 2013) e da Teoria da Tradução Intersemiótica (PLAZA, 2013) a fim de identificar como um trecho da peça foi transposto para a tela. Além disso, tendo em vista os modos de acesso às obras aqui analisadas, busco enfatizar como a Cultura da Convergência e a Cultura Participativa (JENKINS, 2009) estão presentes na forma de produção, divulgação e recepção de produtos midiáticos.

Minha escolha pela peça 4.48 Psychosis (KANE, 2001) como objeto de estudo se deu devido a dois motivos: o primeiro foi o seu contexto de produção, sendo a única peça da escritora a ser encenada postumamente, além da polêmica que a temática do texto, somada ao suicídio de Sarah Kane, gerou a respeito de a peça ser (ou não ser) um bilhete 
de suicídio da autora, o que discuto na seção seguinte. O segundo motivo foi que, além do vídeo analisado estar disponível no YouTube, até o momento da escrita do presente artigo, não há uma tradução oficial da peça publicada em português brasileiro e as duas versões traduzidas de 4.48 Psychosis a que tive acesso nesse idioma não são oficiais e também estão disponíveis na internet (KANE, 2004; KANE, 2017), permitindo, assim, a realização deste estudo comparado entre peça de teatro, tradução interlingual não oficial, adaptação para as telas e sua disseminação na internet, como reflexos da Cultura da Convergência e da Cultura Participativa.

A partir do exposto nesta "Introdução", o artigo está dividido nas seguintes seções: "Referencial Teórico", em que por meio de subseções apresento aspectos sobre a vida e a obra de Sarah Kane, a peça 4.48 Psychosis e sua estrutura, notas sobre a Cultura da Convergência e a Cultura Participativa, e, apontamentos sobre as Teorias da Adaptação, da Tradução Interlingual e da Tradução Intersemiótica. Seguindo, nas “Análises”, desenvolvo uma análise comparativa entre a peça de Kane (2001, 2004, 2017) e a adaptação (PSICOSE 4h48, 2012), enfatizando aspectos como estrutura geral - estrutura dramatúrgica, estrutura dramática, personagens, organização espacial e dispositivo narrativo. Por último, as "Considerações Finais" que foram depreendidas a partir da análise fílmica e de todo o processo de investigação aqui realizado.

\section{REFERENCIAL TEÓRICO}

\section{Notas sobre a vida e a obra de Sarah Kane: a perda de identidade na construção do espetáculo da dor}

Sarah Kane nasceu em Brentwood, Essex, Inglaterra, em 1971. Faleceu em Londres, em 1999 (RAVENHILL, 1999). Desde cedo, a autora demonstrou um interesse obsessivo pela arte dramática, graduando-se em Teatro na University of Bristol e se especializando em Dramaturgia na University of Birmingham (BRNCI'C, 2006).

No decorrer de sua curta vida, escreveu cinco peças de teatro Blasted (1995), Phaedra's Love (1996), Cleansed (1998), Crave (1998) e 4.48 Psychosis (1999) e um roteiro de curta-metragem, Skin (1995). Araújo (2016) caracteriza a obra da escritora como inclinada ao Teatro do Absurdo, devido a "um gosto para o confronto, pelo horror, pelo austero e um senso emocionalmente complexo de percepção cênica" (ARAÚJO, 
2016, p. 22). Bernci'c (2006, p. 40, minha tradução ${ }^{1}$ ) estabelece que a obra de Kane pode ser vislumbrada "como um espetáculo da dor, em que a desintegração do mundo interno das personagens se converte em um correlato da devastação do mundo exterior, encontrando sua forma de expressão através da violência”. Nesse sentido, é importante mencionar que Sarah Kane foi acometida por uma depressão profunda, o que resultou em seu suicídio aos 28 anos de idade.

\begin{abstract}
A breve existência de Sarah Kane foi permeada por uma depressão profunda que a fez transitar por muitos hospitais em busca de um equilíbrio que não pôde conseguir e que a levou, depois de três tentativas falhas de suicídio, a enforcar-se com os cadarços de seus sapatos em um cômodo de hospital (BRNCI'C, 2006, p. 26, minha tradução²).
\end{abstract}

Reflexos de sua depressão e sua passagem por hospitais psiquiátricos podem ser vislumbrados nas peças que escreveu. Araújo (2016) denomina como "trilogia da perda de identidade" as três últimas obras de Kane, pois constroem gradativamente o apagamento e a destruição da personagem em decorrência da construção de uma personagem autorreferencial. Brnci'c (2006) apresenta que drogas, remédios, suicídios e a influência da morte são temas obsessivamente recorrentes ao longo de toda a obra da dramaturga. Todas essas temáticas estão presentes na obra 4.48 Psychosis, escolhida aqui como objeto de estudo e que abordarei a seguir.

\title{
4.48 Psychosis, ou um bilhete velado de suicídio
}

4.48 Psychosis foi a última peça escrita por Sarah Kane. Logo após a escrita da peça, Kane, que estava em um hospital psiquiátrico, veio a cometer suicídio ${ }^{3}$. Muitas são as especulações a respeito de a peça ser um bilhete de suicídio deixado pela dramaturga, devido às semelhanças encontradas entre os escritos e a situação em que Kane se encontrava quando resolveu dar fim à sua vida com as próprias mãos. Čermák, Chrz e

\footnotetext{
${ }^{1}$ No original: "como un espectáculo del dolor, en el que la desintegración del mundo interno de los personajes se convierte en un correlato de la devastación del mundo exterior, encontrando su forma de expresión a través de la violencia" (BRNCI'C, 2006, p. 40).

${ }^{2}$ No original: "La breve existencia de Sarah Kane está cruzada por una profunda depresión que la hizo transitar por múltiples hospitales, en busca de un equilibrio que no pudo conseguir y que la llevó después de tres intentos fallidos de suicidio a ahorcarse con los cordones de sus zapatos en una pieza de hospital' (BRNCI'C, 2006, p. 26).

${ }^{3}$ Armstrong (2015) menciona que devido à proximidade temporal entre o suicídio de Kane e a conclusão de 4.48 Psychosis, muitos argumentaram, e provavelmente continuarão argumentando, que a peça é uma elaborada e complicada nota de suicídio.
} 
Zábrodská (2007) acreditam que a peça seja, de fato, um bilhete de suicídio e que Sarah Kane encontrou sentido na morte, pois sua depressão era um reflexo de uma perspectiva desesperada de compreender a existência humana em um mundo cruel, buscando a resposta para a sua indagação na vida e na arte. "Sarah, finalmente, viu o processo criativo como destrutivo também. É possível pensar que ela encontrou sentido na morte e que, portanto, até o suicídio lhe pareceu uma saída significativa do círculo vicioso [em que se viu imersa]" (ČERMÁK; CHRZ; ZÁBRODSKÁ, 2007, p. 108, minha tradução).

Nossa leitura alternativa do texto 4.48 Psychosis nos forneceu uma compreensão dos motivos de Sarah Kane para seu suicídio. É por isso que podemos concebê-lo como uma nota de suicídio. No entanto, sua peça é muito mais do que isso, e também está claro que não foi escrita principalmente como uma nota de suicídio (ČERMÁK; CHRZ; ZÁBRODSKÁ, 2007, p. 108, minha tradução ${ }^{5}$ ).

Em consonância com o que discutem esses autores, Amaral (2019) chama 4.48 Psychosis de peça-suicídio. “O uso do termo 'peça-suicídio' se justifica, além da ideia de 'última nota' ou um 'bilhete de adeus da autora para com o mundo (seja literário, seja 'real'), no modo como a peça atua: uma tentativa de representação - dolorosa e cruel - da experiência suicida" (AMARAL, 2019, p. 103). Em contrapartida, Moshy (2008) argumenta que tratar 4.48 Psychosis como sendo uma narrativa do suicídio de Sarah Kane obstrui "as passagens (lacunas dramatúrgicas) pelas quais novas contribuições narrativas poderiam, eventualmente, passar. [...] Consequentemente, essa futilidade enterra o texto e sufoca a sua capacidade de se (re)alinhar com futuros artistas e/ou narrativas" (MOSHY, 2008, p. 127, minha tradução $\left.{ }^{6}\right)$.

Do meu ponto de vista, a peça é estruturada a partir da ideia do ato suicida. Possui uma narrativa não linear, composta por trechos fragmentados em que não é possível definir o momento em que começam ou se iniciam as ações, tampouco quem ou quantos são os

\footnotetext{
${ }^{4}$ No original: "Sarah finally saw the creative process as destructive as well. It is possible to think that she found meaning in death, and that therefore even suicide appeared to her as a meaningful exit from the vicious circle" (ČERMÁK; CHRZ; ZÁBRODSKÁ, 2007, p. 108).

${ }^{5}$ No origninal: "Our alternative reading of the text Psychosis 4.48 has provided us with an understanding of Sarah Kane's motives for her suicide. That is why we can conceive of it as a suicide note. However, her play is also much more than that, and it is also clear that it was not written primarily as a suicide note" (ČERMÁK; CHRZ; ZÁBRODSKÁ, 2007, p. 108).

${ }^{6}$ No original: "the passageways (dramaturgical gaps) through which new contributing narratives might eventually pass. [...] Consequently, this futility buries the text and stifles its ability to realign with future artists and/or narratives" (MOSHY, 2008, p. 127).
}

Revista X, v. 16, n. 6, p. 1792-1822, 2021. 
personagens que proferem os diálogos. Brnci'c (2006, p. 26, minha tradução ${ }^{7}$ ) interpreta que 4.48 Psychosis é um monólogo, com diferentes vozes narrativas, "que se projeta da morte para a morte, sendo entrelaçado por uma enumeração caótica de medicamentos ansiolíticos, antidepressivos, calmantes, soníferos e analgésicos, que procuram adiar o fim inevitável e, ao mesmo tempo, desejado". Fordyce (2011) explana que a voz narrativa e as vozes na peça se misturam de uma forma não hierárquica, não sendo possível dizer com precisão se a peça é em primeira ou em terceira pessoa onisciente ou, ainda, se é a própria peça quem está falando. “4.48 Psychosis constitui a 'morte do autor' em forma de peça, na medida em que elimina o cenário, a voz autoral, a voz narrativa e a voz das personagens em anéis concentricamente hierárquicos" (FORDYCE, 2011, p. 112, minha tradução ${ }^{8}$.

Acerca da estrutura da peça, Čermák, Chrz e Zábrodská (2007) dizem que, apesar de ter sido escrita para o palco, o texto é muito incomum nesse sentido, pois possui muitas partes líricas, imagens visionárias internas e quase não há nenhum enredo ou história explícita por trás delas. Amaral (2019, p. 117) acrescenta que, conforme o final da peça se aproxima, "os espaçamentos entre as linhas se tornam mais frequentes e longos. As frases perdem suas continuações, se embaralham em uma página cada vez mais vazia. Lemos as últimas partes da peça de Sarah Kane como um anúncio do fim: a morte se aproxima”. Sobre 4.48 Psychosis no Brasil, Araújo (2016) comenta que é a obra de Kane mais conhecida e montada no país. Sobre a sua tradução ao português brasileiro,

durante muitos anos, só havia a tradução não oficial (não foi publicada, nem impressa ou comercializada) de Laerte Mello para essa obra dramatúrgica em função da sua primeira montagem no ano de 2004, em ocasião do festival de teatro de Curitiba, as demais escrituras [peças] só vieram a ser traduzidas para o português pelo próprio Laerte ou por grupos independentes que encenaram pontualmente algumas escrituras e resolveram disponibilizar o material via PDF pela rede mundial de computadores (ARAÚJO, 2016, p. 18-19).

Além da tradução feita por Laerte Mello, inicialmente, para fins de performance (KANE, 2004), Willian André e Lara Luiza Oliveira Amaral, investigadores da obra de

\footnotetext{
${ }^{7}$ No original: "que se proyecta desde y hacia la muerte, cruzado por la enumeración caótica de decenas de fármacos, ansiolíticos, antidepresivos, calmantes, somniferos, analgésicos, que buscan demorar y desviar el fin ineludible y a la vez ansiado" (BERNCI'C, 2006, p. 26).

${ }^{8}$ No original: "constitutes a 'death-of-the-author' play in that it does away with setting, authorial voice, narrative voice, and character voice in concentrically hierarchical rings" (FORDYCE, 2011, p. 112).
} 
Kane, realizaram uma outra tradução (KANE, 2017), em edição específica dos tradutores, sem fins lucrativos e publicada no site "literatura : suicídio". A tradução de André e Amaral (KANE, 2017) possui notas de tradução a fim de nortear os leitores e as leitoras acerca de algumas de suas escolhas tradutórias, e foi feita a partir da publicação da peça na obra completa da dramaturga em inglês (KANE, 2001) e do cotejo com a tradução do texto teatral realizada por Mello (KANE, 2004).

Destarte, o acesso à obra em português brasileiro só foi possível devido às traduções não oficiais que, graças ao advento das tecnologias acabaram sendo divulgadas na internet, permitindo que brasileiras e brasileiros interessados na obra de Sarah Kane pudessem usufruir de seus textos em sua língua nativa, corroborando a ideia de que "novas tecnologias midiáticas permitiram que o mesmo conteúdo fluísse por vários canais diferentes e assumisse formas distintas no ponto da recepção" (JENKINS, 2009, p. 38). Nesse sentido, afirmo que essas traduções não oficiais que circulam na internet consolidam-se como parte da Cultura da Convergência e da Cultura Participativa, as quais apresento com mais detalhes na próxima seção.

\section{Cultura da Convergência e Cultura Participativa: transformações tecnológicas e interação midiática, ou sobre a mudança no modo de se encontrar com os textos}

De acordo com Jenkins (2009, p. 29), convergência é um termo que se refere "ao fluxo de conteúdo através de múltiplas plataformas de mídia, à cooperação entre múltiplos mercados midiáticos e ao comportamento migratório dos públicos dos meios de comunicação". Observa-se que convergência passa a definir, atualmente, muitas das relações que temos com a tecnologia no nosso dia a dia, tendo em vista que "é uma palavra que consegue definir transformações tecnológicas, mercadológicas, culturais e sociais" (JENKINS, 2009, p. 29), e que nossos hábitos e formas de ter acesso ao lazer e à cultura, em especial, estão dependentes, muitas vezes, de telas e da nossa imersão nas mesmas, seja por meio de redes sociais, plataformas de vídeos on-line, plataformas de streaming para assistir a filmes e séries, entre outras.

Nesse sentido, ao observar o acesso às traduções não oficiais de 4.48 Psychosis feitas por Mello (KANE, 2004) e por André e Amaral (KANE, 2017), noto como a Cultura

\footnotetext{
${ }^{9} \mathrm{O}$ site "literatura : suicídio" é destinado à divulgação de pesquisas, eventos e publicações que versem sobre literatura e suicídio. Na página, encontram-se informações sobre os pesquisadores e pesquisadoras, sobre o projeto de extensão e sobre a origem do grupo de estudos e de pesquisa. Mais informações: https://literaturasuicidio.wordpress.com/.
} 
da Convergência e também a Cultura Participativa ${ }^{10}$ se fazem presentes a partir do meio de divulgação e recepção dessas traduções: a internet. Ao considerar aqui texto original e traduções não oficiais circulando em diferentes meios e suportes, por exemplo: a peça escrita em inglês (KANE, 2001) faz parte de um livro impresso, publicado pela Editora Bloomsbury e chega até o público por meio da compra em livrarias físicas (e também virtuais); a peça traduzida ao português (KANE, 2004; KANE, 2017), por sua vez, não teve, ainda, uma edição impressa publicada e comercializada por alguma editora, mas chega aos leitores e às leitoras por meio da internet, em formato virtual. Essa informação vai ao encontro do paradigma da convergência mencionado por Jenkins (2009, p. 3233), "se o paradigma da revolução digital presumia que as novas mídias substituiriam as antigas, o emergente paradigma da convergência presume que novas e antigas mídias irão interagir de formas cada vez mais complexas".

Além da complexidade na coexistência entre textos escritos em mídias impressas e em mídias virtuais, faço menção ao outro objeto de estudo deste artigo, a adaptação Psicose 4 h48 (2012). Como destaca Jenkins (2009, p. 377), a convergência define "o fluxo de conteúdos através de várias plataformas de mídia, [...] e o comportamento migratório da audiência, que vai a quase qualquer lugar em busca das experiências de entretenimento que deseja". Nessa perspectiva, entendo que a Cultura da Convergência e a Cultura Participativa são resultantes das novas possibilidades de consumo, interação e produção geradas pela internet, como o YouTube, por exemplo, e tantas outras plataformas de mídia on-line, que se tornaram um lugar de rápida difusão de conteúdo, onde seus usuários e usuárias podem ter vez e voz.

Em suma, a Cultura da Convergência e a Cultura Participativa auxiliaram em uma maior divulgação de obras e estimularam a tradução no meio digital. Surge uma nova maneira de produção e compartilhamento de conteúdo que resulta em uma participação ativa de quem produz e/ou de quem lê, possuindo a liberdade para serem tanto consumidores e consumidoras quanto produtores e produtoras também. Como afirma Jenkins (2009, p. 29), “a circulação de conteúdos - por meio de diferentes sistemas de mídia, sistemas administrativos de mídias concorrentes e fronteiras nacionais - depende fortemente da participação ativa dos consumidores [e consumidoras]".

${ }^{10}$ Jenkins (2009, p. 378) define que Cultura Participava é a "cultura em que fãs e outros consumidores [e consumidoras] são convidados a participar ativamente da criação e da circulação de novos conteúdos". 


\section{Sobre tradução e adaptação: prelúdio à peça de teatro transmutada}

Jakobson (1973), em sua Teoria da Comunicação, propôs uma classificação sobre as maneiras de traduzir que mais tarde veio a se tornar um marco para as pesquisas nos Estudos da Tradução. Segundo esse autor, a tradução de signos verbais pode ser classificada em:

1) Tradução intralingual ou reformulação (rewording) [que] consiste na interpretação dos signos verbais por meio de outros signos da mesma língua.

2) Tradução interlingual ou tradução propriamente dita [que] consiste na interpretação dos signos verbais por meio de alguma outra língua.

3) Tradução intersemiótica ou transmutação [que] consiste na interpretação dos signos verbais por meio de sistemas de signos não verbais (JAKOBSON, 1973, p. 64-65, grifos do autor).

A partir dessa abordagem, a análise realizada na seção posterior deste artigo está inserida na segunda classificação, ao considerar as traduções não oficiais de um idioma para outro como reflexos da cultura participativa e da convergência. Também se insere na terceira classificação elencada por Jakobson (1973), ao analisar a tradução intersemiótica do texto escrito da peça de teatro para o audiovisual. Sob o mesmo ponto de vista, Diniz (1998, p. 314) discute que "a relação entre textos dramáticos e filmes" é um exemplo de tradução intersemiótica, pois "o teatro mostra-se como um meio verbal, porém não exclusivamente, enquanto o cinema mostra-se, principalmente, mas não exclusivamente, como um meio visual" (DINIZ, 1998, p. 314).

Quando traduzimos do teatro para o cinema, alguns elementos considerados como peculiares ao teatro serão transformados em outros, especificamente cinematográficos. É a própria procura pela equivalência, ou seja, pelos aspectos que rotulo de intersemióticos, aqueles decorrentes do fato de que o cinema e o teatro possuem propriedades distintivas resultantes de meios diferentes. No cinema seriam, por exemplo, a montagem, recursos de iluminação, a filmagem. São, portanto, fatores intrínsecos, forças internas que atuam sobre as traduções/filmes (DINIZ, 1998, p. 316).

Além disso, nesta investigação, considero o vídeo como uma adaptação da peça de teatro, pois, assim como Hutcheon (2013), defendo a adaptação como uma obra autônoma que adquire esse caráter a partir da recepção, tendo em vista que a audiência que tem acesso a uma obra adaptada sem conhecer a obra inicial à qual está relacionada, 
não sabe que essa adaptação é uma adaptação. Para Hutcheon (2013) a adaptação, assim como a tradução, transcodifica um sistema de comunicação para outro.

Plaza (2013) também discute que a tradução de um signo ${ }^{11}$ para outro não é uma mera transferência entre sistemas. Dentre as formas de transmutação, o autor considera a tradução intersemiótica como uma transcriação de formas, o que acaba por abarcar diferentes signos, uma retextualização. Desse modo, na tradução intersemiótica, os signos utilizados transformam-se em "novos objetos imediatos, novos sentidos e novas estruturas que, pela sua própria característica diferencial, tendem a se desvincular do original" (PLAZA, 2013, p. 30). Portanto, segundo esse autor, nem tudo o que se encontra na obra literária é traduzido por meio da tradução intersemiótica, por exemplo, mas, sim, traduz-se tudo aquilo que nos interessa dentro de determinado processo criativo.

Nessa perspectiva, de acordo com Seger (2007), uma recriação é necessária, pois tudo precisa ser repensado, reconceituado, tendo em vista a natureza dos signos que estão sendo transpostos, no caso, da peça de teatro para o vídeo. Partindo do discutido por essa autora, a adaptação para o audiovisual é uma forma de condensação da trama, tendo em vista a quantidade de páginas que há em um livro e a duração de um filme. Cabe ao adaptador "descobrir como fazer para adequar o material original a parâmetros de tempo diferentes" (SEGER, 2007, p. 18). Enfatizo que a duração/tempo variam de acordo com o tamanho do filme e o gênero literário que está sendo adaptado, bem como questões de linguagem literária que passarão a ser transmutadas para a linguagem audiovisual.

Ao analisar a adaptação de uma peça de teatro para o audiovisual, Diniz (1998) chama a atenção para os signos cinematográficos e para os signos teatrais. Cada sistema de signos pode ser compreendido como um construto de significados. Quando juntos, esses sistemas constituem os aspectos intersemióticos da tradução. Portanto, entendo que as noções de tradução intersemiótica embasam a análise de como o signo disposto textualmente na peça de teatro foi representado no vídeo. Defendo, ainda, a autonomia das obras adaptadas, portanto considero o vídeo Psicose $4 h 48$ sim, como uma adaptação da peça de teatro 4.48 Psychosis, contudo é uma obra independente e autônoma no que tange à fidelidade para com o texto de partida.

\footnotetext{
${ }^{11}$ Plaza (2013, p. 21) define que "o signo é algo que, sob certo aspecto, representa alguma coisa para alguém, dirige-se a alguém, isto é, cria na mente desta pessoa um signo equivalente ou talvez um signo mais desenvolvido".
} 


\section{ANÁLISE E DISCUSSÃo}

\section{A psicose em cena (ou em tela): análise da adaptação de 4.48 Psychosis compartilha- da no YouTube}

Como apresentado na "Introdução", meu objetivo é realizar uma análise da adaptação Psicose 4 448 (2012) a partir da peça 4.48 Psychosis (KANE, 2001) e de suas traduções não oficiais ao português brasileiro (KANE, 2004; KANE, 2017). Minha investigação foi pautada no proposto pelas Teorias da Adaptação (SEGER, 2007; HUTCHEON, 2013) e da Tradução Intersemiótica (DINIZ, 1998; PLAZA, 2013) e como a Cultura da Convergência e a Cultura Participativa (JENKINS, 2009) impactaram no processo de produção, divulgação e recepção da obra. A discussão foi estruturada a partir do que dispõem Vanoye e Goliot-Lété (1994) acerca da análise fílmica de uma adaptação, levando em consideração aspectos como estrutura geral - estrutura dramatúrgica, estrutura dramática, personagens, organização espacial e dispositivo narrativo, como apresento a seguir.

\section{Estrutura geral - Estrutura dramatúrgica}

A adaptação Psicose $4 h 48$ (2012) está disponível para acesso na plataforma de compartilhamento de vídeos on-line YouTube pelo canal tabavideoprodutora (Figura 1). No título do vídeo e nos créditos iniciais, há informações relativas à data de realização da adaptação, à atriz Tatyana Figueiredo e também à autoria de Sarah Kane, não contendo informações sobre quem traduziu o excerto performado em tela, sobre quem dirigiu a adaptação, tampouco informações referentes à produção e ao roteiro da obra audiovisual. Todavia, cheguei até o nome do diretor da adaptação, Wellington Duran, através de situações proporcionadas pela convergência ${ }^{12}$. Por essas características, enquadro essa adaptação no que Jenkins (2009) chama de cinema digital, que, para o autor, diz respeito a filmes produzidos com câmeras digitais, principalmente, aos que são produzidos e distribuídos na internet.

\footnotetext{
${ }^{12}$ A partir do nome da atriz indicado no vídeo, e aproveitando a facilidade de acesso a informação propiciada pela convergência, realizei uma pesquisa na rede social Instagram e encontrei o perfil da atriz Tatyana Figueiredo (@tatyanafigueiredo). Através do chat dessa rede social, perguntei se ela era a atriz do vídeo e solicitei novas informações sobre a produção e a direção. Gentilmente, Tatyana me passou o perfil de Wellington Duran (@wellingtonduran), produtor e diretor da adaptação, que de imediato respondeu minhas perguntas virtualmente. Disponibilizo, como "Apêndice" deste artigo, a entrevista feita com Duran (2021).
} 
Nesse sentido, evidencia-se a Cultura Participativa e a convergência no momento em que os realizadores optaram por compartilhar a adaptação no YouTube, uma vez que, conforme Duran (2021), o vídeo não foi pensado, inicialmente, como um curtametragem, mas, sim, como um monólogo para o portfólio da atriz Tatyana Figueiredo. A peça foi adaptada para o audiovisual para que Tatyana concorresse a uma bolsa de estudos no curso de cinema do Studio Fátima Toledo, de São Paulo. Somente o melhor vídeo com a melhor atuação seria contemplado e, Psicose 4 h48 (2012) foi o vencedor em meio a cinco mil inscritos. Cabe destacar aqui que tanto o projeto quanto a montagem da adaptação não contaram com financiamento e que o vídeo não chegou a ser exibido em nenhum festival.

Figura 1: Abertura de Psicose $4 h 48$ com informações sobre a produção (0:02)

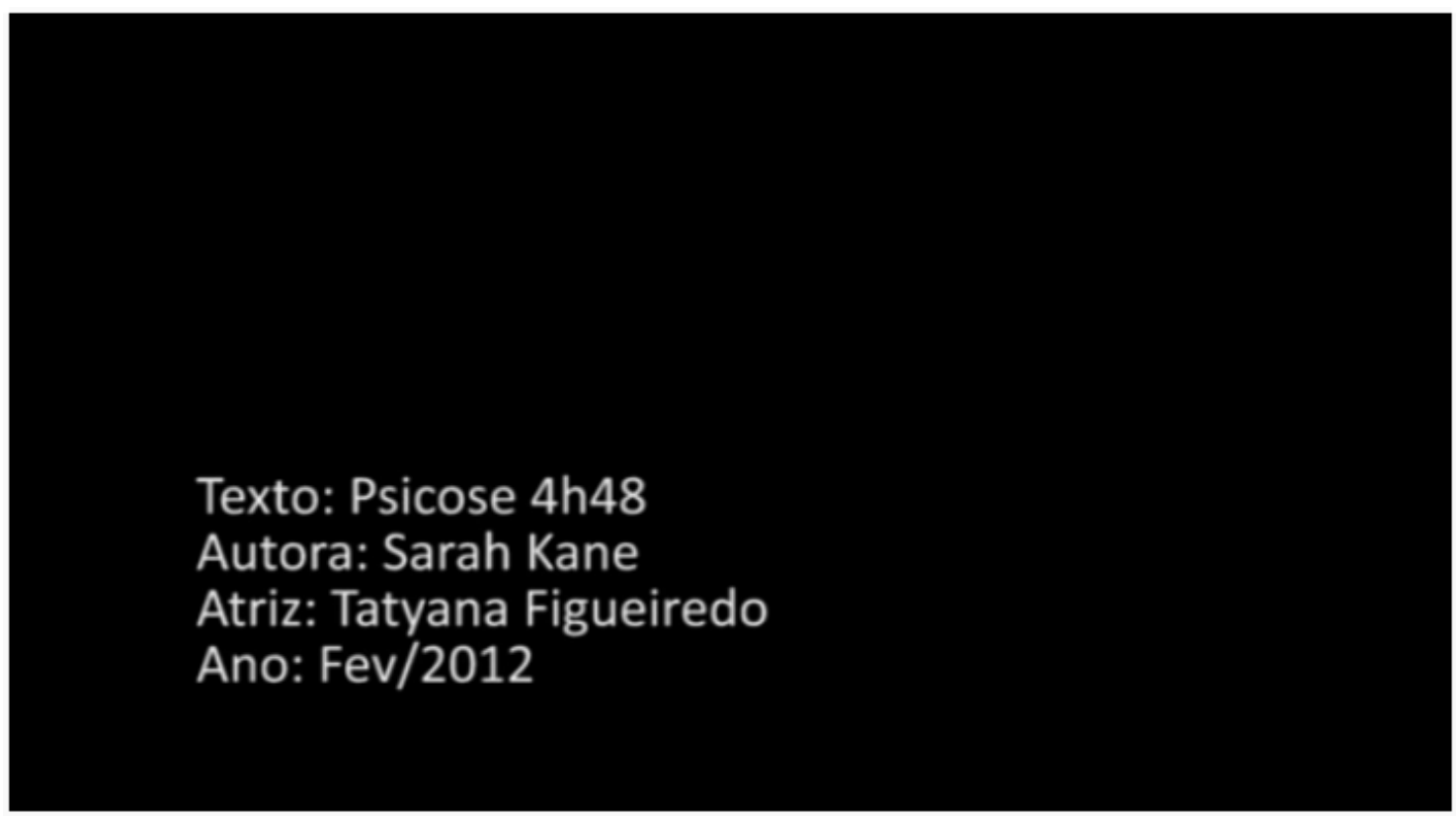

Psicose 4h48 - Sarah Kane - (Atriz: Tatyana Figueiredo)

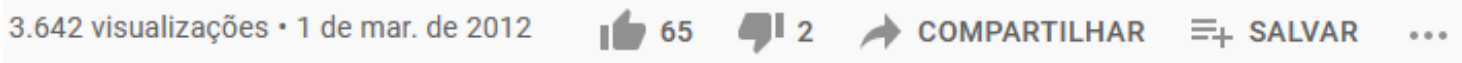

Fonte: Captura de tela realizada pelo autor em 09 ago. 2021

A peça e suas traduções têm entre 27 e 52 páginas, variando conforme a edição e o formato utilizado. As encenações do texto completo para o palco têm entre 50 e Revista X, v. 16, n. 6, p. 1792-1822, 2021. 
90 minutos $^{13}$, variando conforme a montagem realizada. É um texto dramático que não apresenta linearidade, tampouco uma escrita dita convencional de peças de teatro em que são observadas as descrições das personagens, cenário e notas de encenação. As rubricas encontradas no texto ora estão entre parênteses indicando silêncios e silêncios longos ora estão soltas no texto, o que, por vezes, acabam sendo confundidas com a narrativa abstrata e não linear da peça. A adaptação tem duração de 4 minutos e 12 segundos (4:12) e foi realizada a partir da tradução ${ }^{14}$ de dois quadros ${ }^{15}$ sequenciais da peça. Essa escolha por interpretar no filme um único momento da peça e não interpretá-la na íntegra ou de forma condensada/expandida, corrobora o que Hutcheon (2013) e Seger (2007) argumentam acerca da adaptação e sua autonomia, visto que, como Seger menciona, quem faz a adaptação é responsável por adequar o texto a parâmetros de tempos diferentes para as telas. Ressalto, também, o caráter do cinema digital sobre o qual discute Jenkins (2009), pois a duração do filme é adequada à circulação na internet, onde consumidores e consumidoras acabam preferindo materiais audiovisuais de curta duração.

\section{Estrutura dramática}

Conforme Chramosilová (2013), a peça é uma representação da jornada de um/ uma paciente durante a hospitalização e faz uma crítica ao sistema de saúde mental. Essa autora analisa a jornada da seguinte forma: psicose, admissão, médicos/médicas, medicação, interação médico-paciente, alta, recaída e suicídio.

O título da peça é um elemento-chave e o horário das 4h48 se torna um símbolo (cf. PLAZA, 2013) na medida em que a narrativa vai sendo construída. No início do texto, 4 h48 se refere à hora do desespero e da decisão do autoaniquilamento, sendo o momento escolhido para o ato suicida, o momento em que a personagem planeja se enforcar. Seguindo a narrativa, em meio a devaneios, $4 \mathrm{~h} 48$ torna-se a hora da sanidade, o momento em que a personagem estará sã, lúcida e consciente de suas ações, indo de encontro com a simbologia da morte exposta no mesmo momento anteriormente. 4h48 é também a hora em que a personagem irá dormir até surgir um novo 4h48, cuja chegada da claridade, da hora feliz, retoma a simbologia inicial: o ato suicida.

\footnotetext{
${ }^{13}$ Cheguei a estes números consultando algumas montagens que estão disponíveis no YouTube.

${ }^{14}$ Os diálogos do vídeo não utilizaram nenhuma das traduções por mim analisadas (KANE, 2004; KANE, 2017). Duran (2021) não soube informar o nome de quem traduziu a versão por ele adaptada.

${ }^{15}$ A peça não apresenta a designação de quadros, contudo optei por chamar assim para facilitar quando acredito que se encerra uma cena e se inicia outra. Essa distinção, no texto, é apresentada por meio de traços ou filetes.
} 
O trecho da peça que foi utilizado na adaptação aqui analisada é o segundo, ou seja, $4 \mathrm{~h} 48$ como a hora da sanidade. A seguir, apresento um excerto do texto utilizado em 4 h48 Psicose, bem como suas traduções interlinguais não oficiais feitas do inglês ao português brasileiro. Estas traduções (Quadro 1) estão disponíveis on-line e, pelo fato de terem sido realizadas "informalmente" para fins de performance, como no caso de Kane (2004) e, "academicamente" para fins de pesquisa, como no caso de Kane (2017), fazem parte das chamadas Cultura Participativa e Cultura da Convergência (JENKINS, 2006) devido ao modo pelo qual foram produzidas e são compartilhadas na internet.

- At 4.48

when sanity visits

for one hour and twelve minutes I am in my right mind.

When it has passed I shall be gone again,

a fragmented puppet, a grotesque fool.

Now I am here I can see myself (KANE, 2001).

Quadro 1: Excertos das traduções não oficiais de Kane (2001) em português brasileiro

\begin{tabular}{|c|c|c|}
\hline Tradução de Laerte Mello & $\begin{array}{c}\text { Tradução de Willian André } \\
\text { e Lara Luiza Oliveira } \\
\text { Amaral }\end{array}$ & Transcrição da adaptação \\
\hline & - Às 4:48 & - Às $4 \mathrm{~h} 48$ \\
\hline - Às 4.48 & quando a sanidade vem & é quando a sanidade vem me \\
\hline quando a sanidade visita & por uma hora e doze minutos & visitar \\
\hline por uma hora e doze minutos & eu fico com a cabeça & por uma hora e doze minutos \\
\hline eu fico com a mente no lugar. & certa. & fico em sã consciência. \\
\hline $\begin{array}{c}\text { Quando isso tiver passado eu } \\
\text { terei ido outra vez, }\end{array}$ & $\begin{array}{l}\text { Assim que passar, vou estar } \\
\text { perdida de novo, }\end{array}$ & $\begin{array}{l}\text { Depois disso me vou outra } \\
\text { vez, }\end{array}$ \\
\hline $\begin{array}{l}\text { uma marionete fragmentada, } \\
\text { um bufão grotesco. }\end{array}$ & $\begin{array}{l}\text { um fantoche fragmentado, } \\
\text { uma idiota grotesca. }\end{array}$ & $\begin{array}{l}\text { uma boneca fragmentada, } \\
\text { uma imbecil grotesca. }\end{array}$ \\
\hline $\begin{array}{l}\text { Agora estou aqui eu consigo } \\
\text { me ver (KANE, 2004). }\end{array}$ & $\begin{array}{l}\text { Agora que estou aqui, eu } \\
\text { consigo me ver (KANE, } \\
\text { 2017). }\end{array}$ & $\begin{array}{l}\text { Eu tô aqui. Eu consigo me } \\
\text { ver (PSICOSE 4h48, 2012, } \\
\quad \text { minha transcrição). }\end{array}$ \\
\hline
\end{tabular}

Fonte: Organizado pelo autor (2021) 
Mesmo que o filme tenha adaptado o trecho em que 4h48 é a hora da sanidade, a tradução intersemiótica da cena irá mostrar o contexto da personagem solitária, em uma tentativa de representação da depressão, das perturbações psicológicas e mentais em que se encontra. Como exposto no excerto acima (Quadro 1), a tradução interlingual utilizada na adaptação tem algumas diferenças linguísticas quando comparada com as demais traduções não oficiais e a performance da atriz transparece a naturalidade empregada no monólogo a partir de certas marcas de oralidade.

A opção em rodar a peça de Sarah Kane, e essa cena em especial, foi uma escolha do diretor visando a alcançar o pretendido pelo Studio Fátima Toledo e seu método exclusivo de preparação de atores. Como relata Duran (2021, n.p.), ao observar que a referida escola de cinema "sempre exige o máximo de imersão psicológica das personagens para obter atuações verborrágicas, esse trecho de 4 h48 Psicose, no meu ponto de vista, preenchia as necessidades do processo por conta da visceralidade com a qual teríamos que conduzi-lo".

Nesse sentido, torna-se nítido que a fisionomia e a atuação de Tatyana Figueiredo (Figura 2), que interpreta a personagem, fazem com que a adaptação ${ }^{16}$ da peça para $o$ audiovisual seja uma tradução do desespero, da depressão e da loucura, em contraponto com a lucidez, ressaltando as características concernentes à linguagem audiovisual. Como destaca Diniz (1998, p. 314), “os textos se baseiam em palavras e imagens, o que ilustra a simultaneidade [...] dos elementos verbal e visual, embora um deles sempre predomine". Nesse caso, os signos interpretados visualmente retratam o profundo caos interior da personagem:

\footnotetext{
${ }^{16}$ Para maiores informações sobre o processo criativo da adaptação da peça para o vídeo, ler a resposta de Duran (2021) à pergunta 3, no "Apêndice" deste artigo. 
Figura 2: Frame de Psicose 4 h48 (2:25)

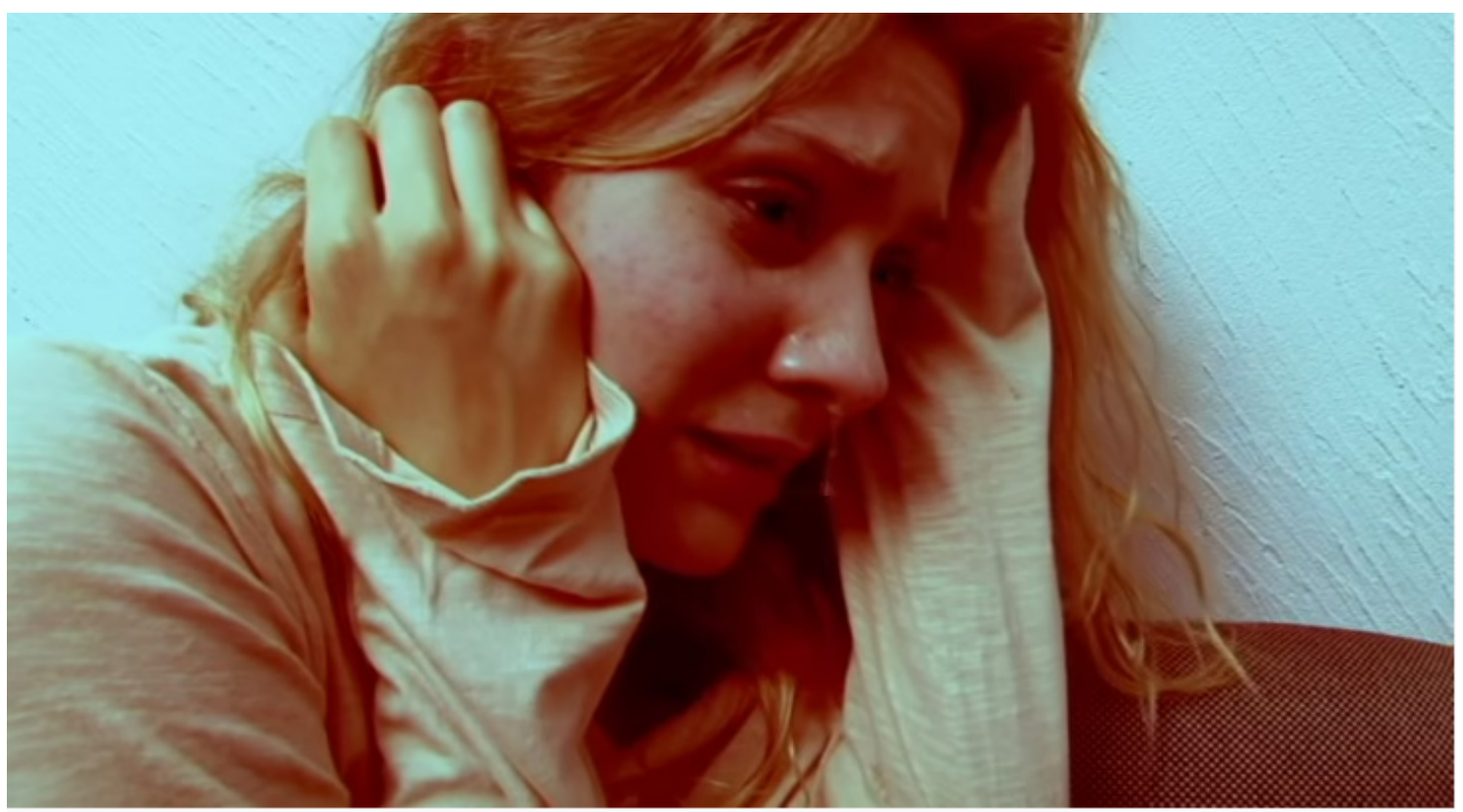

Fonte: Captura de tela realizada pelo autor em 09 ago. 2021

\section{Personagens}

Em 4.48 Psychosis (KANE, 2001) não há uma indicação explícita sobre a quantidade de personagens que compõem a narrativa, tampouco descrições de gênero, idade ou características físicas de personagens. Ambas as traduções interlinguais feitas do inglês ao português brasileiro (KANE, 2004, 2017) retratam a personagem principal da peça como sendo do gênero feminino ${ }^{17}$, o que pode ser explicado devido a certas marcas linguísticas enraizadas na língua portuguesa. Chramosilová (2013) menciona que isso também ocorreu em traduções da peça para o tcheco, língua que também possui marcações de gênero, nas quais a personagem principal foi retratada como uma mulher e a personagem médica, como um homem. Isso não costuma ser o caso do inglês, em que substantivos e adjetivos, por exemplo, não possuem desinência de gênero e, então, a interpretação das personagens da peça dependerá do imaginário de quem está lendo.

\footnotetext{
${ }^{17}$ Nem a tradução de Laerte Mello (KANE, 2004) nem a tradução de Willian André e Lara Luiza Oliveira Amaral (KANE, 2017) trouxeram explicações ou notas de tradução que justificassem essa escolha.
} 
Partindo da mesma perspectiva das traduções não oficiais brasileiras, a adaptação para o YouTube optou por retratar uma personagem principal de gênero feminino, sozinha. Duran (2021, n.p.) comenta que a escolha por uma personagem mulher se deu devido ao fato de que o principal objetivo da adaptação era a inscrição de Tatyana Figueiredo à bolsa do curso de cinema. Contudo, o diretor afirma que a escolha "de uma personagem feminina forte, autêntica e densa foi pensada a fim de expor artisticamente um universo que vem sendo cada vez mais estudado e explorado por conta do aumento das patologias psíquicas".

Como discute Hutcheon (2013, p. 43), “o que está envolvido na adaptação pode ser um processo de apropriação, de tomada de posse da história de outra pessoa, que é filtrada, de certo modo, por sua própria sensibilidade, interesse e talento". Nessa perspectiva, a adaptação audiovisual apresentou escolhas para transmutar um trecho da peça de teatro para as telas utilizando apenas uma personagem e seu monólogo, porém, no processo criativo da adaptação, o diretor chegou a se vestir com um jaleco de médico psiquiatra, confeccionado previamente, e passou a se dirigir à atriz como "Sarah Kane", fazendo-a confundir-se com a personagem ${ }^{18}$.

A personagem interpretada por Tatyana Figueiredo é uma mulher anônima, branca, pálida, loira e nitidamente deprimida. Usa uma camisa clara de manga-longa que, por vezes, remete à representação sígnica de uma camisa de força ou de uma roupa de hospital, de alguém que está internada. Diniz (1998, p. 315) apresenta que, na tradução intersemiótica para o cinema, "o trabalho da câmera e o processo de edição influenciam muito o significado dos elementos da mise-en-scène". Nessa perspectiva, como estratégias para retratar o desespero e o sofrimento da personagem, a produção conta com o uso de cenas em primeiro e primeiríssimo planos, os quais deixam em evidência as lágrimas no rosto da mulher, seu nariz escorrendo e seu olhar angustiado (Figura 3).

\footnotetext{
${ }^{18}$ Para mais detalhes, ler a resposta da pergunta 3, no "Apêndice" deste artigo. 
Figura 3: Frame de Psicose 4 h48 (3:22)

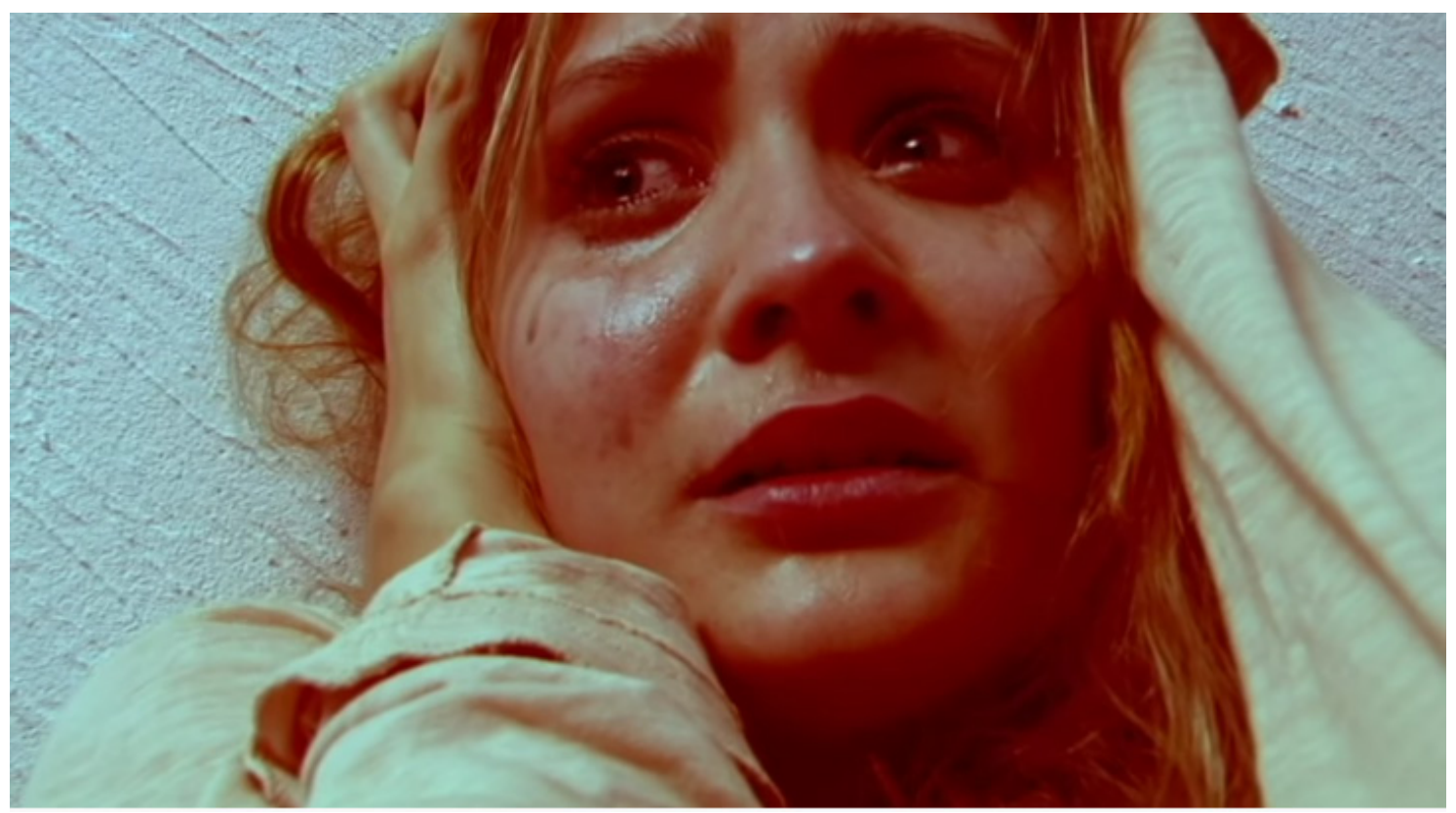

Fonte: Captura de tela realizada pelo autor em 09 ago. 2021

\section{Organização espacial}

A nebulosidade na peça de teatro que não permite afirmar com precisão tratar-se de uma ou mais personagens, também se faz presente no quesito organização espacial. Não há a descrição de cenários ou de espaços e ambientes, tampouco informações sobre o tempo da narrativa. Algumas interpretações da peça (CHRAMOSILOVÁ, 2013; AMARAL, 2019) dizem tratar-se de um hospital psiquiátrico em que a personagempaciente é admitida e, por meio de frases e números, aparentemente desconexos, é possível identificar lembranças, perguntas e respostas entre médico/médica e paciente, bem como um teste feito para que a paciente seja admitida no hospital. Na adaptação para o cinema digital (Figura 4), a organização espacial é composta por uma parede clara e, o cenário, por um sofá marrom em que a personagem está em cima. Duran (2021, n.p.) explica que "queria que fosse tudo muito cru, para passar a maior naturalidade e realidade possível". Não é possível visualizar portas nem janelas ou outros móveis na composição do ambiente. 


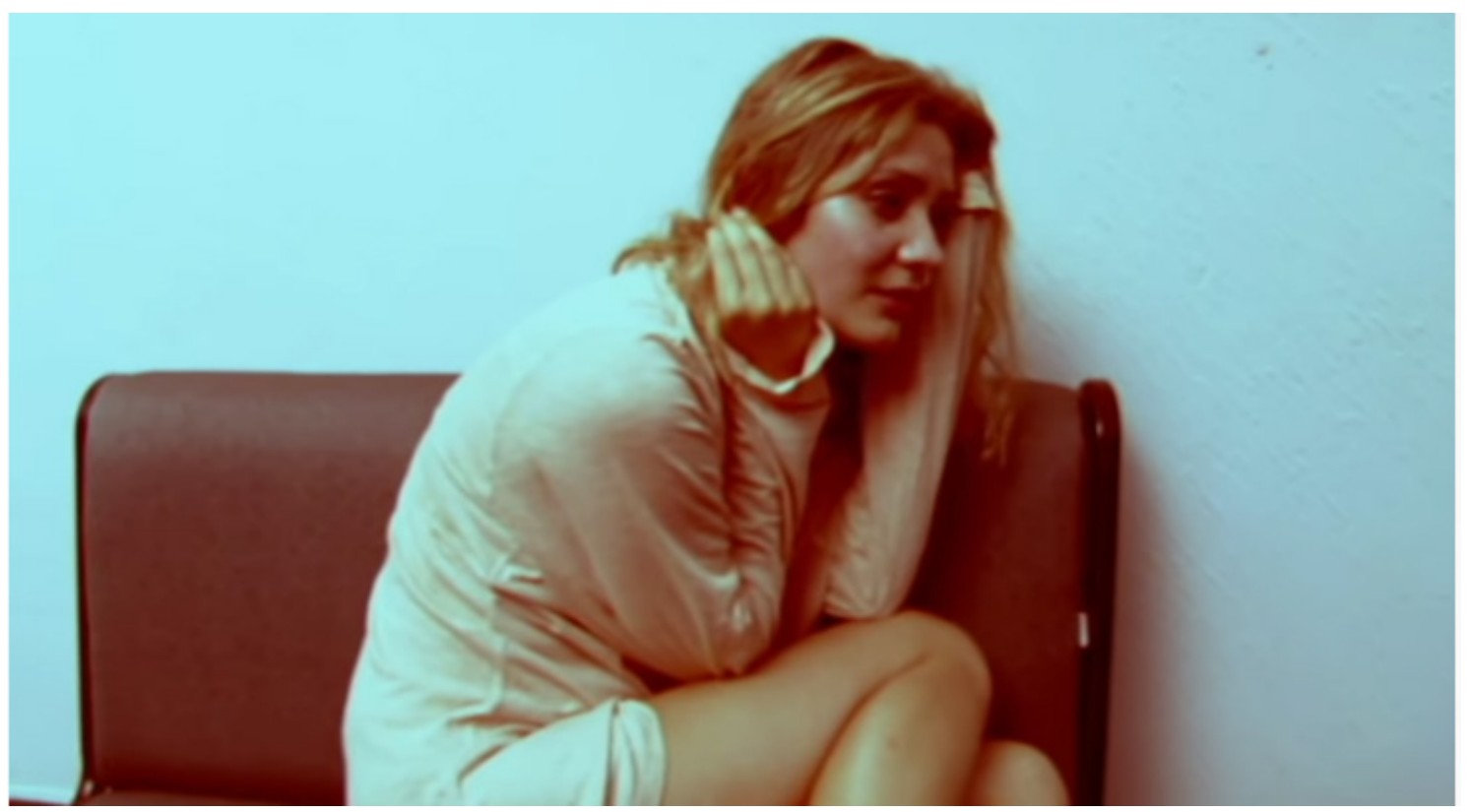

Fonte: Captura de tela realizada pelo autor em 09 ago. 2021

\section{Dispositivo narrativo}

Diniz (1998) apresenta que o sistema de signos cinematográficos é constituído não só de imagens, mas também de palavras, música e ruídos. Posto isso, no início da adaptação ouve-se um áudio em volume baixo. No áudio, há vozes falando em línguas estrangeiras, não sendo possível compreender as palavras ou frases que estão sendo ditas em sua totalidade. Devido a chiados que, por vezes, são escutados, o som parece sair de um aparelho de televisão ou de rádio. Em momentos pontuais, surge uma interferência que se sobressai ao áudio, ocultando o som das falas estrangeiras. Juntamente com esse áudio surge a trilha sonora instrumental da adaptação, delicada, sutil, com notas altas e baixas que permitem que em certos momentos do filme, conforme a intensidade no tom de voz da personagem que profere seu monólogo, o áudio de fundo em línguas estrangeiras seja ouvido. Tanto a música instrumental quanto o áudio com vozes em línguas estrangeiras permanecem como plano de fundo do começo ao fim da adaptação. Nessa perspectiva, “a música oferece 'equivalentes' auditivos para as emoções das personagens, e, assim, provoca reações afetivas no público; o som, de modo geral, pode acentuar, reforçar, ou até mesmo contradizer os aspectos visuais e verbais" (HUTCHEON, 2013, p. 48). 
As vozes de fundo que entrelaçam o monólogo da personagem no filme podem ser comparadas à consciência ou a vozes que talvez não existam, mas insistem em ecoar na profundidade da mente da personagem. Concebemos as vozes como um signo que representa a alucinação, a depressão e os ecos do suicídio (Figura 5), pois, conforme Armstrong (2015, p. 179, minha tradução ${ }^{19}$ ), "usando convenções teatrais e discurso poético, Kane chama a atenção para conceitos modernos da doença mental", o que também é representado categoricamente na adaptação compartilhada no YouTube. Assim sendo, podemos compreender as vozes de fundo como a tradução do delírio, da psicose:

Figura 5: Frame de Psicose 4 h48 (0:21)

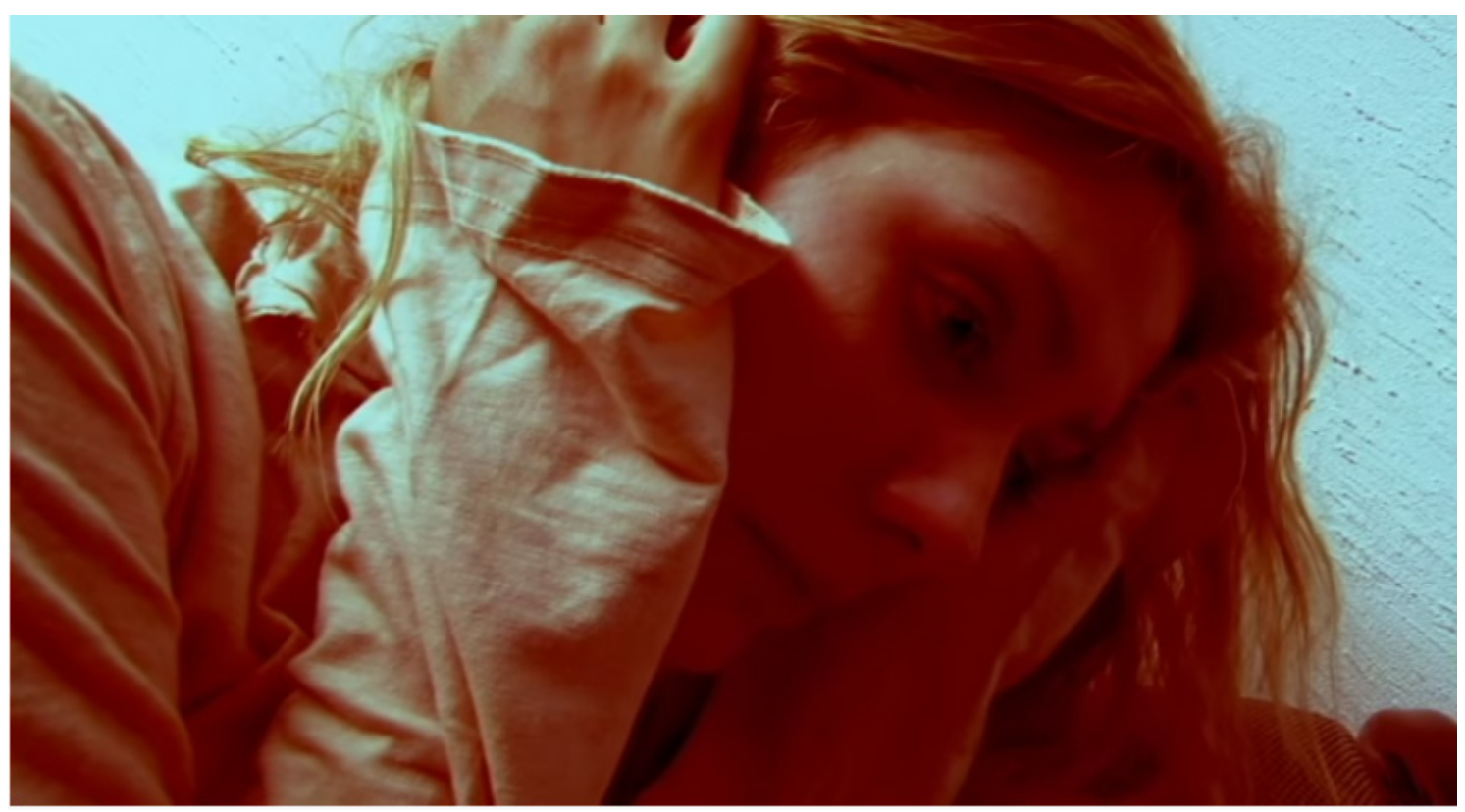

Fonte: Captura de tela realizada pelo autor em 09 ago. 2021

Duran (2021, n.p.) comenta que não elaborou nada muito técnico em relação à direção de fotografia, direção de arte, sonorização e remasterização, pois queria transmitir a sensação "de a personagem estar totalmente fragilizada e, praticamente, passível a qualquer situação de vulnerabilidade [...]. Na edição da cena foi extraído um mínimo de som, advindo de barulhos da rua e acrescentada uma coloração levemente avermelhada".

Saliento que as cores são outro recurso utilizado como dispositivo narrativo na construção do cinema digital. Em 4 h48 Psicose, a cor está presente na narrativa enquanto

${ }^{19}$ No original: "Using theatrical conventions and poetic speech Kane draws attention to modern conceptions of mental illness" (ARMSTRONG, 2015, p. 179).

Revista X, v. 16, n. 6, p. 1792-1822, 2021. 
signo, pois não é apenas algo que se vê, mas também aquilo que constitui um elemento que sustenta percepções do real. Os tons pálidos na roupa, na pele, no cabelo e na parede, traduzem a fragilidade, a doença; o vermelho, como sombra/iluminação, eleva a experiência da psicose, do desespero. As cores, sua ausência e sua ênfase, permitem que a audiência que assiste à adaptação faça novas assimilações a partir de um mesmo objeto, pois como Hutcheon $(2013$, p. 48) aborda, "as representações visuais [...] são ricas em associações complexas".

Armstrong (2015) discute que a fragmentação da linguagem e a dispensa de uma estrutura formal na escrita, por exemplo, facilitam a expressão do tipo de sentimento que Sarah Kane desejava encenar em 4.48 Psychosis. Essa fragmentação textual encontra lugar no suicídio retratado na peça como a fragmentação do ser, um ato de representação do fim voluntário. Porém, como argumenta Chramosilová (2013, p. 17, minha tradução ${ }^{20}$ ), “a percepção de 4.48 Psychosis apenas como 'arte suicida' ou um retrato de uma desintegração da mente humana seria obscura e confinada", dessa forma, reitero a multiplicidade de temáticas passíveis de novas interpretações depreendidas da leitura dessa peça de teatro, como as que mencionei na análise acerca da estrutura dramática, por exemplo.

No filme, é possível estabelecer uma relação com essa analogia sobre a desintegração do ser e a cena final da adaptação, na qual, por meio de recursos audiovisuais, vê-se a fragmentação da imagem através do desfoque da câmera, em primeiríssimo plano (Figura 6), enquadrando uma personagem reflexiva e fora de si, questionando os reais motivos de sua própria existência, até que a claridade da cena (e por que não a lucidez da personagem?) atinja a escuridão total. Como expõe Diniz (1998), entre as características exclusivas do cinema para a tradução intersemiótica, encontram-se o trabalho com a câmera, os planos e a edição. Portanto, a partir dessas questões técnicas, a fragmentação do ser é traduzida, na adaptação, por meio da fragmentação da imagem em tela.

${ }^{20}$ No original: "The perception of 4.48 Psychosis as 'suicide art' only or a portrait of a disintegration of the human mind would be dim and confined" (CHRAMOSILOVÁ, 2013, p. 17). Revista X, v. 16, n. 6, p. 1792-1822, 2021. 


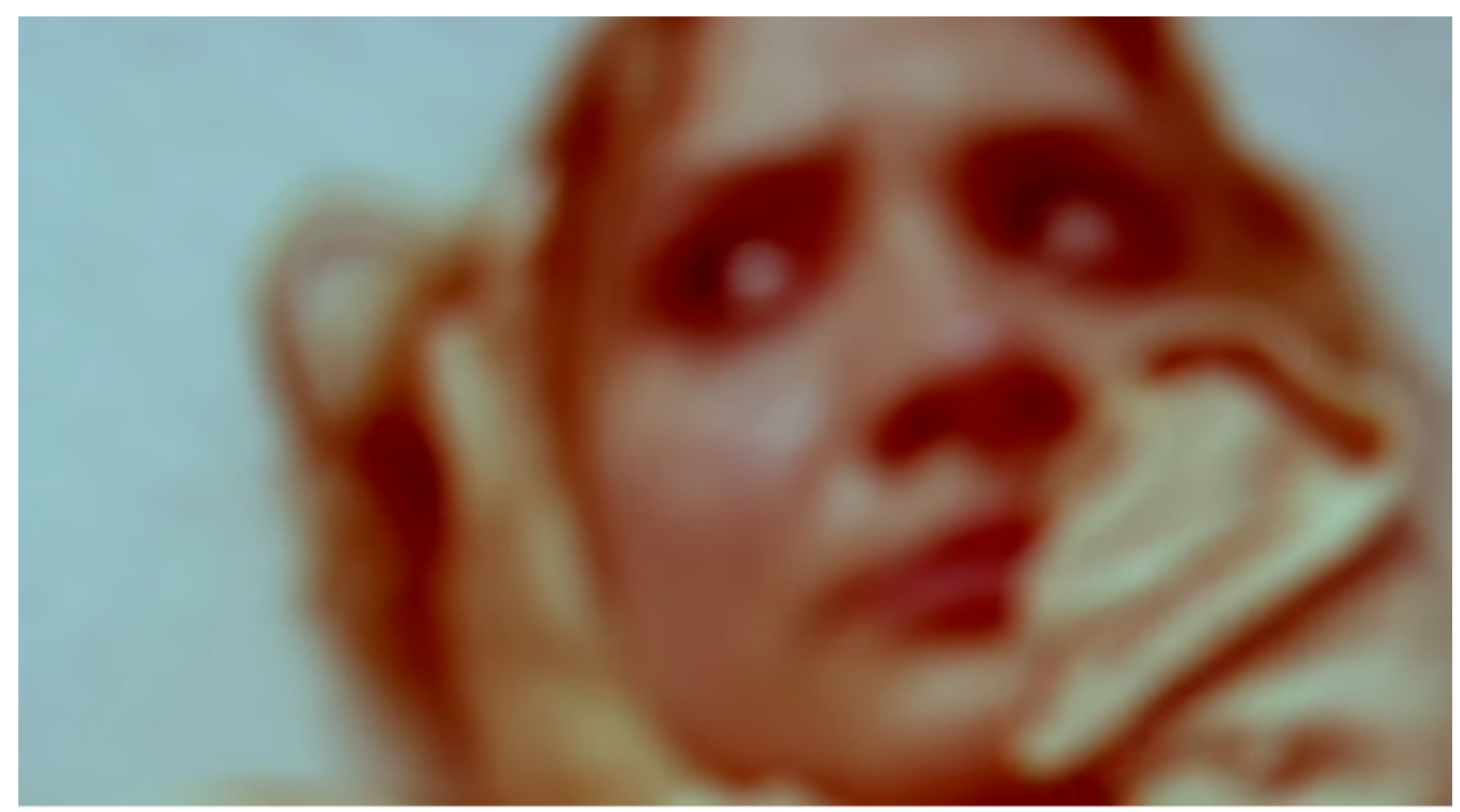

Fonte: Captura de tela realizada pelo autor em 09 ago. 2021

Retomando as características da plataforma de compartilhamento de vídeos YouTube, um dos aspectos que essa plataforma permite a seus usuários e usuárias é a interação entre a audiência consumidora e produtores e produtoras de conteúdo que ali compartilham suas produções audiovisuais. Como Jenkins (2009, p. 44) discute, "a convergência dos meios de comunicação impacta o modo como consumimos esses meios". O público contemporâneo não é mais composto por sujeitos passivos, cujos modos de interação só são possíveis de forma presencial. Agora, com o advento da tecnologia digital e com as produções midiáticas, nos encontramos inseridos cada vez mais em uma Cultura Participativa, participando ativamente de processos antes, durante e depois de o produto ser consumido. A Figura 7 ilustra dois comentários feitos pela audiência que assistiu à adaptação na internet, o que só foi possível devido ao compartilhamento dessa obra no meio virtual. 
Figura 7: Comentários de espectadores sobre $4 h 48$ Psicose (2012) no YouTube

\section{C \\ Negra Noite. 7 anos atrás \\ .. $\mathrm{N}$,tenho uma palavra pra exprimir o Q-senti.. \\ 1 ال RESPONDER \\ (ᄂ) \\ Lari Antigo 8 anos atrás \\ Muito bom !!! \\ II RESPONDER}

Fonte: Captura de tela realizada pelo autor em 09 ago. 2021

Um aspecto que chama a atenção no comentário de Negra Noite é a liberdade de escrita e de expressão da linguagem que foge às convenções e às regras ortográficas e gramaticais. A audiência na internet está se reinventando e modificando o meio para além das telas, criando uma linguagem específica, aceita e compreendida pela comunidade de usuários on-line. Além disso, essas interações da audiência com a adaptação e com os demais usuários e usuárias que assistirão ao vídeo são reflexos da Cultura da Convergência e da Cultura Participativa, o que reitera o caráter autônomo da adaptação enquanto obra independente e a intenção por trás de sua produção e de seu compartilhamento no YouTube.

\section{CONSIDERAÇÕES FINAIS}

Neste artigo, busquei realizar uma análise a fim de identificar como a peça 4.48 Psychosis foi transposta para o audiovisual por meio da adaptação Psicose 4h48. Para tanto, apresentei, brevemente, um levantamento bibliográfico sobre a vida e a obra de Sarah Kane, expus algumas características acerca dos objetos de estudos, sobre a Cultura da Convergência e a Cultura Participativa, como seu impacto na sociedade está mudando a forma de participação da audiência e o que entendo por Adaptação, Tradução Intersemiótica e Tradução Interlingual.

A partir da pesquisa bibliográfica, desenvolvi uma análise comparativa entre peça de teatro, suas traduções não oficiais e sua adaptação para o audiovisual compartilhada 
no YouTube, ambas disponíveis virtualmente na internet, o que eleva a importância de se discutir a convergência nesse processo. Nas análises, identifiquei como trechos do texto escrito foram traduzidos para a tela, a força da linguagem não verbal e da tradução e representação dos signos, bem como a simbologia das cores em uma obra que versa sobre depressão, psicose e suicídio.

Reitero a ausência de obras traduzidas de Sarah Kane no Brasil. Enfatizo que até o momento da escrita deste artigo não existem obras da escritora publicadas e traduzidas oficialmente para o português brasileiro. Sendo assim, o acesso à obra de Kane, inclusive em língua inglesa, torna-se de difícil acesso ao público brasileiro, o que também influencia no baixo número de pesquisas desenvolvidas no país acerca da dramaturgia kaneana. Defendo a necessidade da tradução da obra completa da escritora para o português brasileiro, visando a difundir sua produção teatral comercialmente para a audiência brasileira.

Nesse ínterim, saliento o papel que a Cultura da Convergência e a Cultura Participativa, conforme Jenkins (2009), está exercendo no que tange às mudanças tecnológicas, industriais, culturais e sociais e no modo como as mídias circulam em nossa cultura e como a audiência está recebendo essas mídias. Nessa perspectiva, a situação imposta pela pandemia de Covid-19 fez com que formas de interações artísticas tivessem seus modos de produção, divulgação e recepção modificados. Enfatizo o caráter que a convergência entre as mídias operou nessa mudança, a exemplo das novas formas de produção teatral que mencionei na "Introdução" deste artigo.

Ainda no que tange à Cultura da Convergência e à Cultura Participativa, destaco o processo de pesquisa que realizei no Instagram, a fim de contatar, diretamente, atriz e diretor da adaptação, que, de forma exitosa resultou na entrevista que compartilho no "Apêndice" deste trabalho. É preciso um olhar mais atento da academia, neste caso, da área de Letras, para essas questões, acompanhando e defendendo pesquisas que versem sobre obras literárias, audiovisuais, suas adaptações e outros objetos de estudos que são, muitas vezes, rejeitados por serem considerados não canônicos, como os por mim aqui analisados.

\section{AGRADECIMENTOS}

Agradeço à Cynthia Beatrice Costa, à Dirce Waltrick do Amarante, ao Henrique Pezzini, à Tatyana Figueiredo e ao Wellington Duran. Quero agradecer, ainda, às pessoas que deram o parecer e avaliaram este artigo, por apresentarem questionamentos imprescindíveis para chegar ao texto final aqui publicado 


\section{REFERÊNCIAS}

AMARAL, Lara Luiza Oliveira. "Para os não nascidos": a peça-suicídio de Sarah Kane. Criação \& Crítica, São Paulo, n. 23, p. 103-119, abr., 2019. DOI: https://doi. org/10.11606/issn.1984-1124.v23i23p103-119.

ARAÚJO, Rummenigge Medeiros de. A tanatopoética de Sarah Kane: escritos para a morte. 2016. 300 f. Tese (Doutorado) - Programa de Pós-Graduação em Estudos da Linguagem, Universidade Federal do Rio Grande do Norte, UFRN, Natal, 2016.

ARMSTRONG, Jolene. Cruel Britannia: Sarah Kane's postmodern traumatics. Bern: Peter Lang, 2015.

BRNCI'C, Carolina. Sarah Kane y el espectáculo del dolor. Revista Chilena de Literatura, Santiago, n. 69, p. 25-43, nov., 2006. DOI: http://dx.doi.org/10.4067/S071822952006000200002.

ČERMÁK, Ivo; CHRZ, Vladimir; ZÁBRODSKÁ, Kateřina. "4.48 Psychosis” as a Suicide Note of Sarah Kane? In: ROBINSON, David; KELLY, Nancy; MILNES, Kate. Narrative and Memory. Huddersfield: University of Huddersfield, 2007. p. 111-119.

CHRAMOSILOVÁ, Martina. Beyond the Suicidal Despair: An Analysis of Sarah Kane's 4.48 Psychosis. 2013. 51 f. Thesis (Bachelor in English and American Studies) Department of English and American Studies, Faculty of Arts, Masaryk University, Brno, 2013.

DINIZ, Thaïs Flores Nogueira. Tradução Intersemiótica: do texto para a tela. Cadernos de Tradução, Florianópolis, v. 1, n. 3, p. 313-338, 1998. DOI: https://doi.org/10.5007/\%25x.

DUBATTI, Jorge. Experiencia teatral, experiencia tecnovivial: ni identidad, ni campeonato, ni superación evolucionista, ni destrucción, ni vínculos simétricos. Rebento, São Paulo, v. 1, n. 12, p. 8-32, jan./jun., 2020.

DURAN, Wellington. Sobre a adaptação Psicose 4h48. Destinatário: Willian Henrique Cândido Moura. [s. 1.], 08 mar. 2021.9 mensagens eletrônicas. 
FORDYCE, Ehren. The voice of Kane. In: DE VOS, Laurens; SAUNDERS, Graham (Eds.). Sarah Kane in Context. Manchester: Manchester University Press, 2011, p. 103-114.

HUTCHEON, Linda. Uma Teoria da Adaptação. Tradução de André Cechinel. 2. ed. Florianópolis: Editora da UFSC, 2013.

JAKOBSON, Roman. Linguística e Comunicação. Tradução de Izidoro Blikstein e José Paulo Paes. 6. ed. São Paulo: Cultrix. 1973.

JENKINS, Henry. Cultura da Convergência. Tradução de Susana Alexandria. 2. ed. São Paulo: Aleph, 2009.

KANE, Sarah. “4.48 Psyshosis”. In: KANE, Sarah. Sarah Kane: complete plays. Introdução de David Greig. Londres: Bloomsbury, Methuen Drama, 2001.

KANE, Sarah. 4.48 Psicose. Tradução de Laerte Mello. [s.1.], 2004. Disponível em: https://pt.scribd.com/doc/46025569/Psicose-4-48-Sarah-Kane. Acesso em 20 mar. 2021.

KANE, Sarah. Psicose 4:48. Tradução de Willian André e Lara Luiza Oliveira Amaral. [s.1], 2017. Disponível em: https://literaturasuicidio.files.wordpress.com/2017/11/ psicose-4-48-sarah-kane.pdf. Acesso em 20 mar. 2021.

MOSHY, Summer Neilson. The Empty Center: Acting out theatric alliance in three texts by Sarah Kane. 2008. 201 f. Dissertation (Ph.D. in Drama and Theatre) - University of California, San Diego, 2008.

PLAZA, Julio. Tradução Intersemiótica. 2. ed. São Paulo: Perspectiva, 2013.

PSICOSE 4h48 - Sarah Kane, 2012. 1 vídeo (4 min). Publicado pelo canal tabavideoprodutora. Disponível em: https://www.youtube.com/watch?v=pwmt5CrSyvw. Acesso em 09 ago. 2021.

RAVENHILL, Mark. Obituary: Sarah Kane. The Independent. Independent Digital News and Media, 23 Fev. 1999. Disponível em: http://www.independent.co.uk/artsentertainment/obituary-sarah-kane-1072624.html. Acesso em: 20 mar. 2021.

SEGER, Linda. A Arte da Adaptação: como transformar fatos e ficção em filme. Tradução de Andrea Netto Mariz. São Paulo: Bossa Nova, 2007. 
VANOYE, Francis; GOLIOT-LÉTÉ, Anne. Ensaio sobre a análise fílmica. Tradução de Marina Appenzeller. Campinas: Papirus, 1994.

WEXEL, Juliana. Teatro, audiovisual e streaming: uma análise sobre o fazer teatral em tempos de incerteza pandêmica na experiência pós-dramática da peça Esperando Godette. Rotura, Faro, v. 1, p. 39-46, 2021. DOI: https://doi.org/10.34623/sxc1-he90. 


\section{APÊNDICE}

\section{Sobre a adaptação Psicose $4 \mathrm{~h} 48$}

Entrevista concedida a Willian Moura, por Wellington Duran (2021), via WhatsApp.

Wellington Duran é ator e diretor de teatro e cinema. Atualmente, é diretor geral do Teatro Artaud, escola de teatro e cinema especializada na formação de atores, localizada em Atibaia, São Paulo. Em sua trajetória profissional, destacam-se, como diretor, Love \& Revenge (2019), In the Room (2021) e, como ator, In Carcere et Vinculis (2014), Abismo (2014) Escondido (2016), e A Quarentena (2020), primeira websérie realizada inteiramente com câmeras de celulares e com direção totalmente remota.

\section{1- Por que a peça foi adaptada para o vídeo?}

A peça 4.48 Psychosis foi adaptada com o objetivo de alcançar um resultado positivo no concurso aberto para bolsa de estudos, $100 \%$ off, do Curso de Cinema do Studio Fátima Toledo (Escola de Cinema), em que apenas o melhor vídeo seria premiado. Conseguimos o feito em meio a mais de cinco mil vídeos inscritos.

\section{2 - Por que você optou por rodar, especificamente, essa cena da peça?}

A opção em rodar a peça de Sarah Kane, e essa cena em especial, foi uma escolha minha como diretor, haja vista que conhecendo o método que a Fátima Toledo trabalha na preparação de atores, e observando que a mesma sempre exige o máximo de imersão psicológica das personagens para obter atuações verborrágicas, esse trecho de 4.48 Psychosis, no meu ponto de vista, preenchia as necessidades do processo por conta da visceralidade com a qual teríamos que conduzi-lo.

\section{3 - Como ocorreu o processo criativo da adaptação?}

O processo de criação já vinha ancorado em anos de trabalho com a atriz Tatyana Figueiredo, uma vez que eu prestava o trabalho de direcionamento da sua carreira (coaching de atores). Sabendo do seu potencial interpretativo e de sua coragem em acessar universos deslocados da sua realidade, primeiro conversei com a atriz e expliquei o que teríamos que trazer à tona na cena, ou seja, intensidade emotiva máxima. A partir daí, expus que o texto de 4.48 Psychosis poderia nos levar a esse propósito, pois a Fátima Toledo trabalha dentro de uma linha tênue entre ator/personagem em que ambos se fundem em benefício do nascimento de uma cena estritamente verdadeira e real. 
Iniciei, então, um trabalho de mesa com a atriz, estudando a vida e a obra de Sarah Kane, não apenas 4.48 Psychosis, mas também outras peças como Cleansed, Blasted e Phaedra's Love. Isso trouxe o entendimento das questões humanas da personagem. Na sequência, tive uma conversa com a Tatyana na qual deixei claro que a parte de preparação para imersão na personagem seria desafiadora e "violenta" no sentido de optar por trabalhar muito a questão da memória emotiva em todos os âmbitos técnicos e também pessoais, para que, no momento que antecedesse o take, pudéssemos racionalizar as emoções despertadas sem perder a intensidade máxima liberada no processo.

Entreguei o fragmento de cena escolhido do texto da Sarah nas mãos da Tatyana e pedi para que ela estudasse e encontrasse por si mesma, para o primeiro ensaio, o contexto da personagem dentro do seu universo pessoal. Onde estava a insanidade velada da atriz Tatyana Figueiredo? Quando nos encontramos, a atriz apresentou a cena de forma rasa e estritamente técnica. Eu disse que não era nada daquilo que nós precisaríamos para conceber a cena e atingir nosso objetivo. Então, ela me explicou que seu professor de interpretação da universidade disse que ela precisava, como atriz, pensar muito na técnica, especialmente a análise ativa e fugir o máximo possível da memória das emoções. Eu retruquei e disse que para essa cena, não. Ela teria que fazer uma opção: ou ficava com a colocação de seu professor e faria o vídeo sem minha ajuda como preparador da cena, ou confiava na minha direção que já havia tido sucesso em festivais de teatro, levando-a a premiação de melhor atriz em uma das etapas do Mapa Cultural Paulista. Eu não abria mão disso. Ou do meu jeito ou não daria continuidade ao processo de criação e ela teria a opção de partir para outro diretor. $\mathrm{Na}$ época éramos namorados, mas separávamos muito bem o lado profissional do pessoal. Ela chorou muito e foi para casa pensar. Refleti comigo: se ela confiar e aceitar minha proposta, esse primeiro momento vai servir e muito para o processo de imersão, para a densidade da cena.

No dia seguinte, Tatyana muito leve e feliz me disse que confiava plenamente e aceitava somente meu processo sem interferência externa de outra pessoa. A partir disso, iniciei o processo de imersão sem ela se dar conta de que já estava nele. Comecei a falar que ela não acreditava em mim após anos de relações pessoais e profissionais. Que ela iria se arrepender muito, porque precisava ter êxito nessa cena para alcançar seu sonho de atuar em Hollywood, e que jamais conseguiria isso atuando dessa forma. Sabia de todos os seus pontos fracos como pessoa humana, por conta dos anos de relacionamento, e que sua imensa sensibilidade era afetada quando alguma dúvida pairava sobre sua capacidade artística e também em relação a perder o carinho das pessoas que ela mais amava. Joguei pesado com isso até que ela ruiu e se pôs a chorar copiosamente. Quando chegou ao 
extremo e percebi que ela já estava perdida e consumida pelas emoções despertadas, sem ela entender nada, vesti um avental de psiquiatra que havia confeccionado e passei a chamá-la de Sarah Kane, fazendo-a confundir-se com a personagem. Naquele momento ela já não tinha mais condições de parar para pensar quem era: a atriz ou a personagem? O que era real e o que era ilusão naquele jogo de mise-en-scène?

Com a câmera ligada e pausada, disse: isso tudo é um processo para a cena. Agora, racionalize tudo, mas sem perder a emoção despertada. Quando eu der o “Ação!”, é com você. Arrasa! Hollywood está em jogo. Você pode! Você consegue! Rodei a câmera, ela esperou os famosos três segundos e naquele momento ela era a Sarah Kane e todas as outras Sarahs Kanes em cena. Um show de atuação. Foi apenas um take e mais nada. Não precisava repetir, pois sabia que havíamos feito algo muito avassalador.

Após travar a câmera abracei a Taty carinhosamente e, com muito carinho e vários elogios e palavras de incentivo, ela naturalmente foi iniciando um misto de choro e riso, até que somente a felicidade pelo feito estava dentro dela. Sabíamos que tinha dado certo e que era questão de tempo para obtermos o resultado planejado. Dali em diante, nosso carinho e respeito mútuo como diretor/atriz e namorados só aumentou e o resultado foi altamente positivo. $\mathrm{O}$ vídeo foi premiado como o melhor entre os cinco mil inscritos e Tatyana fez o curso completo no Studio Fátima Toledo. A cena ficou como capa do site do Studio por seis meses e, cerca de um ano depois, Tatyana Figueiredo estava nos Estados Unidos, realizando seu sonho em Hollywood.

\section{4 - Teve algum financiamento, verba ou orçamento disponível para o filme?}

O projeto da cena 4.48 Psychosis não teve nenhuma verba ou financiamento. Apenas a vontade de fazer algo que era necessário na época, ou seja, testar nossa capacidade de almejar grandes feitos como diretor e como atriz e obter algum reconhecimento crítico por esse trabalho.

\section{5 - O objetivo inicial sempre foi a circulação e a divulgação da adapação no YouTube?}

Na verdade, o objetivo nunca foi divulgar no YouTube, nem participar de nenhum festival de curtas, pois a cena foi concebida totalmente crua, apenas com a intenção de análise da interpretação da Tatyana. Não elaborei nada altamente técnico em relação à direção de fotografia, direção de arte, figurino, sonorização e remasterização. Queria que fosse tudo muito cru, para passar a maior naturalidade e realidade possível. Usei apenas uma parede de fundo branco de grafiato e uma blusa velha de dormir para dar a sensação de a personagem estar totalmente fragilizada e passível a qualquer situação de vulnerabilidade. 
Somente na edição da cena foi extraído um mínimo de som, advindo de barulhos da rua e acrescentada uma coloração levemente avermelhada.

\section{6 - Quem traduziu o texto que foi utilizado?}

Não sei quem traduziu o texto. Esse texto caiu nas minhas mãos porque, na época, eu estava trabalhando com um elenco grande, no qual a Tatyana era uma das atrizes que estava buscando levantar um texto sobre loucura, D16 - poemas amargos, baseado nas experiências de um ator do elenco acerca de sua internação em uma clínica psiquiátrica por conta de esquizofrenia. O texto era altamente poético e ao apresentá-lo em uma roda de conversa de amigos, um deles citou a similaridade com os textos da Sarah Kane e me enviou para compor minhas pesquisas.

\section{7 - Por que escolheu uma personagem feminina?}

A opção de escolher uma personagem feminina foi em função de ser um pedido da atriz Tatyana Figueiredo para gravar um vídeo para concorrer a uma bolsa no Studio Fátima Toledo, como expliquei anteriormente. Mas a opção pela escolha de uma personagem feminina forte, autêntica e densa foi pensada a fim de expor artisticamente um universo que vem sendo cada vez mais estudado e explorado por conta do aumento das patologias psíquicas.

\section{8 - O vídeo chegou a ser exibido em alguma mostra ou festival?}

O vídeo não foi exibido em nenhum festival, pois, como comentei, era uma proposta direcionada para um único fim: conquistar em meio a cinco mil inscrições o prêmio de melhor vídeo do ano do Studio Fátima Toledo. Ele não foi pensado como um curtametragem, mas sim como um monólogo para o portfólio da atriz Tatyana Figueiredo.

\section{9 - Algo mais que queira acrescentar?}

Sim. A imensa felicidade de ver um trabalho digno tecnicamente, com muito empenho, dedicação e garra durante a sua elaboração, alcançar, agora, um olhar acadêmico. Isso já é um retorno extremamente positivo para nossos anseios, além do objetivo principal da realização do vídeo que foi alcançado com a Tatyana como a ganhadora da bolsa de estudos.

Recebido em: 19 jul. 2021. Aceito em: 18 ago. 2021. 